\title{
IMPLEMENTASI PERATURAN BUPATI NOMOR 6 TAHUN 2016 TENTANG STANDARISASI USAHA PONDOK WISATA DALAM MENINGKATKAN PENDAPATAN ASLI DAERAH KABUPATEN BADUNG PROVINSI BALI
}

\author{
Komang Ayu Kusuma Wardani \\ Fakultas Ilmu Sosial dan Ilmu Politik Universitas Mahendradatta - Denpasar \\ Email : Ayukusumawardani93@gmail.com
}

\begin{abstract}
ABSTRAK, Kabupaten Badung sebagai salah satu daerah yang menerapkan otonomi daerah membentuk suatu kebijakan akomodasi pariwisata yang tertuang dalam Peraturan Bupati Nomor 6 Tahun 2016 tentang Standarisasi Usaha Pondok Wisata. Peraturan ini merupakan tindaklanjut dari penataan dan pengawasan pembangunan jasa akomodasi di Kabupaten Badung, sebagai persyaratan teknis untuk jasa akomodasi dengan lahan sempit dengan mengikuti standar dari usaha pondok wisata. Tujuan dari penelitian ini adalah untuk mengetahui bagaimanakah implementasi, strategi implementasi serta faktor penghambat dan faktor pendukung implementasi Peraturan Bupati Nomor 6 Tahun 2016 tentang Standarisasi Usaha Pondok Wisata. Metode yang digunakan adalah deskriptif kualitatif. Untuk memperoleh data, peneliti melakukan observasi serta wawancara dengan narasumber yang berhubungan dengan implementasi peraturan tersebut. Hasil dari penelitian ini adalah implementasi peraturan ini belum berjalan secara optimal, terjadi pelanggaran dalam penyelenggaran dan perijinannya. Dinas Pariwisata sebagai pelaksana terkesan mengabaikan hal tersebut, dikarenakan pemerintah menginginkan peningkatan pendapatan daerah yang diterima dari penetapan pajak pada usaha sebesar 10\%. Strategi pelaksanaan dikonsepkan ke Desa Wisata, namun untuk pelaksanaan dilapangan tidak sesuai. Faktor pendukung pelaksanaan peraturan ini ialah adanya komunikasi dan kerjasama yang baik antara aktor pelaksana, potensi penataan tata ruang, dan potensi meningkatkan pendapatan asli daerah Kabupaten Badung. Sedangkan faktor penghambatnya ialah keragaman perilaku kelompok sasaran dan tingkat komitmen dan keterampilan aparat pelaksana.
\end{abstract}

Kata Kunci : Implementasi Kebijakan, Peraturan Bupati, Usaha Pondok Wisata, Pendapatan Asli Daerah

\begin{abstract}
Badung district as one of the regions applying local autonomy made a policy of tourism accommodation stipulated in the Regent Regulation Number 6 Year 2016 on Standardization of Cottages Business.This regulation was a follow-up of building structuring \& supervision of accommodation service in Badung District, as a technical requirement for accommodation service with a narrow area of land by following the standard of cottages business. The objectives of this research were to determine how the implementation, implementation strategy and supporting factors are of Regent Regulation Number 6 Year 2016 on the Standardization of Cottages Business. This was a descriptive qualitative research. In order to collect the data, the researchers conducted an observation and interview with information sources relating to the implementation of that regulation.The research result showed that the implementation of this research was not optimum yet, there was a violation of the implementation and the license. Badung tourism service as the executor seems like ignoring that matter since the government wants to have a local revenue increase accepted from the tax determination for business by 10\%. The implementation strategy was conceptualized as a Tourism Village, but the condition at field did not support. Supporting factors of this regulation implementation were communication and good cooperation among the executors, potential of spatial planning implementation, and the potential to increase Badung local own-source revenue. While the inhibiting factors were the target group behavior diversity and commitment degree as well as executors 'ability.
\end{abstract}

KEY WORDS: Policy implementation, regent regulation, cottages business, local own source revenue.

\section{LATAR BELAKANG}

Bali sebagai salah satu provinsi di Indonesia, menjadi tujuan pariwisata yang mengalami perkembangan industri pariwisata khususnya pembangunan sarana akomodasi. Hingga kini, Bali telah memiliki lebih dari 28.000 kamar hotel yang terdiri dari kelas pondok wisata, hotel melati, hingga bintang 
lima. Berkembangnya sarana akomodasi ditujukan untuk mendukung pariwisata dan para wisatawan yang datang, serta merupakan prioritas untuk menyokong pembangunan pariwisata di Bali. Berdasarkan data Badan Pusat Statistik Bali, pertumbuhan akomodasi pariwisata terkonsentrasi di wilayah Bali Selatan, salah satunya ialah Kabupaten Badung. Berkembangnya sarana akomodasi di Kabupaten Badung memberikan dampak positif dan negatif. Dampak positifnya ialah peningkatan pendapatan Kabupaten Badung. Sedangkan dampak negatif yang diterima pemerintah atau masyarakat setempat ialah dampak pada lingkungan dan ruang terbuka hijau.

Menanggapi permasalahan tersebut, Pemerintah Kabupaten Badung memilih untuk melakukan penataan dan pengawasan dengan menerbitkan Peraturan Bupati Nomor 36 Tahun 2016 tentang Standar Minimal Luas Lahan dan Luas Kamar serta Fasilitas Penunjang Hotel dan Kondotel. Namun, berdasarkan hasil rapat koordinasi yang membahas Peraturan Bupati Badung No 36 Tahun 2016 tersebut, ditemukan bahwa terjadi pembangunan sarana akomodasi yang dianggap tidak sesuai dengan luas lahan, yakni luas lahan sempit namun memiliki jumlah kamar banyak.

Oleh karena itu, Pemerintah Kabupaten Badung melalui Dinas Pariwisata, mengusulkan kebijakan untuk sarana akomodasi dengan luas lahan sempit dengan menerbitkan Peraturan Bupati Nomor 6 tentang Standarisasi Usaha Pondok Wisata. Usaha pondok wisata adalah usaha penyediaan akomodasi berupa bangunan rumah tinggal yang dihuni oleh pemiliknya dan dimanfaatkan sebagian untuk disewakan dengan memberikan kesempatan kepada wisatawan untuk berinteraksi dalam kehidupan sehari-hari pemiliknya. Setiap usaha harus melengkapi persyaratan teknis berupa izin usaha, TDUP, sertifikat, dan sertifikasi usaha pondok wisata serta kapasitas penyediaan jumlah kamar paling sedikit satu kamar dan paling banyak lima kamar yang khusus untuk disewakan.

Berdasarkan laporan jasa akomodasi Kabupaten Badung tahun 2016, terdapat 775 usaha pondok wisata yang sudah memiliki izin usaha dan TDUP. Namun masih ada usaha pondok wisata yang belum dapat menunjukan izin atau masih dalam proses pengurusan perijinan namun sudah operasional yang berjumlah 92 usaha. Pelaksanaan Peraturan
Bupati ini terkendala dalam melakukan persyaratan teknis dan proses perijinan seperti IMB dan peruntukkan kapasitas usaha pondok wisata. Pelaksanaan kebijakan ini mengalami kesulitan karena bangunan usaha sudah terbangun terlebih dahulu yang menyebabkan kelebihan kapasitas kamar serta dipengaruhi oleh kepentingan pemerintah dalam meningkatkan pendapatan daerah dengan mengabaikan usaha pondok wisata yang belum memiliki ijin namun berjalan secara opersional.

Berdasarkan penjabaran latar belakang di atas, maka peneliti melakukan penelitian dengan judul "Implementasi Peraturan Bupati Nomor 6 Tahun 2016 tentang Standarisasi Usaha Pondok Wisata dalam Meningkatkan Pendapatan Asli Daerah Kabupaten Badung Provinsi Bali."

\section{METODE PENELITIAN}

Jenis penelitian yang digunakan adalah penelitian deskriptif dengan pendekatan kualitatif. Adapun fokus penelitian ini adalah 1) Implementasi Peraturan Bupati Nomor 6 Tahun 2016 tentang Standarisasi Usaha Pondok Wisata, mencakup (a) penyelenggaraan usaha pondok wisata, (b) Tanda Daftar Usaha Pariwisata (TDUP), Sertifikat Usaha, dan Sertifikasi Usaha Pondok Wisata, (c) Pembinaan dan Pengawasan. 2) Strategi Implementasi Peraturan Bupati Nomor 6 Tahun 2016 tentang Standarisasi Usaha Pondok Wisata, mencakup (a) penyelenggaraan usaha pondok wisata, (b) Tanda Daftar Usaha Pariwisata (TDUP), Sertifikat Usaha, dan Sertifikasi Usaha Pondok Wisata, (c) Pembinaan dan Pengawasan. 3) Faktor Pendukung dan Penghambat Implementasi Peraturan Bupati Nomor 6 Tahun 2016 tentang Standarisasi Usaha Pondok Wisata. Jenis data yang digunakan adalah data primer dan data sekunder, sedangan sumber data yang digunakan ialah informan, peristiwa dan dokumen,. Teknik pengumpulan data, peneliti menggunakan 3 (tiga) teknik pengumpulan data menurut Creswell (2012) yaitu observasi, wawancara, dan dokumentasi. Teknik analisis data menggunakan interactive analysis dari Miles, Huberman, dan Saidana (2014) yang terdiri dari empat alur kegiatan yaitu pengumpulan data, kondensasi data, penyajian data, dan penarikan kesimpulan. 


\section{LITERATURE REVIEW}

Menurut Friendrich dalam Agustino (2016) kebijakan adalah serangkaian tindakan yang diusulkan seseorang, kelompok atau pemerintah dalam suatu lingkungan tertentu dimana terdapat hambatan-hambatan dan kesempatan-kesempatan terhadap pelaksanaan usulan kebijaksanaan tersebut dalam rangka mencapai tujuan tertentu. Sedangkan kebijakan publik menurut Dunn dalam Pasolog (2008) ialah suatu rangkaian pilihan-pilihan yang saling berhubungan yang dibuat oleh lembaga atau pejabat pemerintah yang menyangkut tugas pemerintahan. Grindle (1980) memberikan pandangan tentang implementasi kebijakan dengan mengatakan bahwa secara umum tugas implementasi adalah membentuk suatu kaitan yang memudahkan tujuan-tujuan kebijakan bisa direalisasikan sebagai dampak dari suatu kegiatan pemerintah.

Strategi merupakan seni dan ilmu yang menggunakan dan mengembangan kekuatan (ideology, politik, ekonomi, sosial-budaya dan pertahanan keamanan) untuk mencapai tujuan yang telah ditetapkan (Sumarsono, 2006). Menurut Goldsworthy dan Ashley dalam Salusu (2008), terdapat tujuh aturan dasar dalam merumuskan suatu strategi yaitu harus menjelaskan dan menginterpretasikan masa depan, arahan strategi harus dapat menentukan rencana, strategi harus berfokus pada keunggulan kompetitif, harus diaplikasikan dari atas kebawah, strategi harus mempunyai orientasi eksternal, fleksibilitas adalah sangat esensial dan strategi harus berpusat pada hasil jangka panjang.

\section{HASIL DAN PEMBAHASAN}

\section{Implementasi Peraturan Bupati Nomor 6 Tahun 2016 tentang Standarisasi Usaha Pondok Wisata}

Secara umum penyelengaraan usaha pondok wisata di Kabupaten Badung belum terlaksana secara optimal, usaha cenderung menggunakan istilah villa dibandingan pondok wisata. Hal tersebut dikarenakan masyarakat menganggap pengunaan istilah villa lebih memiliki nilai jual dimata wisatawan. Usaha pondok wisata yang seharusnya sebuah bangunan rumah tinggal dan ditinggali oleh pemiliknya dan sebagian kamar disewakan kepada wisatawan untuk memberikan kesempatan untuk berinteraksi dalam kehidupan sehari-hari, namun pada kenyataannya pemilik menyewakan keseluruhan bangunan. Pada pelaksanaan perijinan, masih terdapat usaha pondok wisata yang belum memiliki izin namun tetap berjalan secara operasional. Pada tahun 2016 terdapat 92 usaha pondok wisata yang belum dapat menunjukkan perizinan usahanya. Pembinaan dan pengawasan oleh pemerintah dilakukan melalui bimbingan teknis dan pelatihan teknis bagi tenaga kerja, namun dilapangan ditemukan bahwa terjadi keengaanan pemilik atau manager usaha untuk mengirimkan pegawainya mengikuti pembinaan, serta terdapat beberapa usaha yang tidak menerima surat undangan dari dinas pariwisata. Pengawasan dilaksanakan selama 5 bulan dalam setahun, dimana tim pengawas turun ke masing-masing kecamatan untuk memberikan pembinaan. Sanksi administrasi dilakukan oleh dinas pariwisata bekerjasama dengan satuan polisi pamong praja, pada tahun 2015-2017 tidak ada laporan usaha pondok wisata yang melakukan pelanggaran, sedangkan berdasarkan penjabaran sebelumnya pelanggaran telah terjadi.

Jika dikaitkan dengan teori implementasi kebijakan Merilee S. Grindle, keberhasilan implementasi Peraturan Bupati Nomor 6 tahun 2016, dapat diukur dari isi kebijakan (content of policy) dan lingkungan kebijakan (context of policy).

a. Isi Kebijakan (content of policy)

1. Kepentingan yang mempengaruhi

Terdapat dua pihak yang berkepentingan dalam pelaksanan peraturan bupati nomor 6 tahun 2016 yaitu Dinas Pariwisata Kabupaten Badung dan pengusaha pondok wisata. Pemerintah berkepentingan dalam mengatur kembali usaha akomodasi dengan lahan sempit menggunakan persyaratan teknis usaha pondok wisata. Sedangkan pengusaha menginginkan usahanya tetap berjalan, walau telah melakukan pelanggaran.

2. Tipe manfaat

Untuk mengantisipasi pembangunan jasa akomodasi dengan lahan sempit namun memiliki banyak kamar, menanggulangi berkurangnya lahan terbuka hijau dan upaya pemerintah dalam meningkatkan daya saing masyarakat menengah kebawah serta meningkatkan PAD Kabupaten Badung.

3. Derajat perubahan yang diharapkan

Perubahan yang diharapkan ialah perubahan perilaku atau pola pikir pengusaha pondok wisata untuk mengikuti kebijakan yang tertuang dalam peraturan bupati sehingga tidak 
ada lagi pengusaha yang membangun usahanya terlebih dahulu kemudian melakukan perijinannya. Serta kebijakan ini diharapkan membawa perubahan yang baik bagi pengusaha jasa akomodasi dengan lahan sempit. 4.

5. Letak pengambilan keputusan

Peraturan bupati nomor 6 tahun 2016 ditetapkan oleh Bupati Kabupaten Badung bersama Dinas Pariwisata yang memiliki wewenang terhadap pelaksanaan kebijakan dibidang kepariwisataan.

6. Pelaksana program

Pelaksana dari peraturan ini antara lain Bupati, Dinas Pariwisata, Dinas Penanaman Modal dan Pelayanan Terpadu Satu Pintu, Satuan Polisi Pamong Praja, Dinas Sosial dan Ketenagakerjaan, Lembaga Sertifikasi Usaha, dan Perhimpunan Hotel dan Restauran Indonesia Kabupaten Badung.

7. Sumber daya yang digunakan

Staff bidang sarana akomodasi seksi akomodasi, tim pembinaan dan pengawasan jasa akomodasi, tim penegak hukum satuan polisi pamong praja Kabupaten Badung menjadi sumber daya manusia yang digunakan, sedangkan sumber daya lainnya berupa sumber dana yang digunakan dalam pelaksanaan kebijakan ini bersumber dari APBD Kabupaten Badung.

b. Lingkungan Kebijakan (context of policy)

1. Kekuasaan, kepentingan-kepentingan dan strategi aktor yang terlibat

Dinas Pariwisata menginginkan semua usaha jasa akomodasi beroperasi secara legal sesuai dengan perundang-undangan yang berlaku. Pemerintah mengabaikan usaha pondok wisata yang belum memiliki izin usaha, menginginkan pendapatan yang diterima dari pajak usaha sesuai dengan jumlah kamar yang disewakan.

2. Karakteristik lembaga dan rezim yang sedang berkuasa

Pemerintah Kabupaten Badung tidak bisa menekan masyarakat untuk melakukan bisnis di bidang akomodasi pariwisata, sehingga pemerintah mengabaikan aturan yang telah dibuat, dan memperbolehkan usaha berjalan secara operasional dengan ketentuan menetapkan pajak usaha melalui NPWPD sesuai dengan jumlah kamar yang disewakan.

3. Tingkat kepatuhan dan adanya respon dari pelaksana

Pengusaha pondok wisata cenderung untuk membangun terlebih dahulu kemudian melakukan perijinan, hal tersebut dilakukan karena mereka merasa kurangnya informasi terkait legalitas jasa akomodasi. Sedangkan pemerintah mengabaikan pelanggaran, dikarenakan memiliki tujuan dalam meningkatkan pendapatan daerah yang diterimanya melalui pajak usaha.

\section{Strategi Implementasi Peraturan Bupati Nomor 6 Tahun 2016 tentang Standarisasi Usaha Pondok Wisata}

Kegagalan kebijakan publik cenderung terjadi dikarenakan tidak adanya strategi yang dipersiapkan aparatur untuk melaksanakan kebijakan. Dinas Pariwisata sebagai leading sector kebijakan yang tertuang dalam Peraturan Bupati Nomor 6 Tahun 2016, hanya merancang strategi pelaksanaan dalam sebuah konsep desa wisata yang memiliki tujuan untuk pengendalian pembangunan jasa akomodasi di kawasan Badung Selatan. Hal ini merupakan sebuah alternatif yang ditawarkan pemerintah kepada wisatawan dalam menikmati alam. Strategi pelaksanaan ini dibagi menjadi 3 cluster wilayah yaitu Kecamatan Mengwi, Kecamatan Abiansemal dan Kecamatan Petang.

Strategi pelaksanaan perijinan usaha dan sanksi administrasi, Dinas Pariwisata Kabupaten Badung mengikuti ketentuan yang tertuang dalam Peraturan Menteri Nomor 86 Tahun 2010 tentang tata cara pendaftaran usaha penyedia akomodasi, Peraturan Menteri Nomor 9 Tahun 2014 tentang standar usaha pondok wisata, dan Peraturan Menteri No 18 tahun 2016 tentang pendaftaran usaha pariwisata. Sedangkan strategi pelaksanaan dalam pengawasan dan pembinaannya, Dinas Pariwisata berdasarkan rekomendasi dari PHRI Kabupaten Badung membentuk suatu tim pembinaan dan pengawasan jasa akomodasi pariwisata berdasarkan surat keputusan Bupati.

\section{Faktor Penghambat dan Faktor Pendukung Implementasi Peraturan Bupati Nomor 6 Tahun 2016 tentang Standarisasi Usaha Pondok Wisata}

1. Faktor Penghambat

a. Keragaman Perilaku Kelompok Sasaran

Kelompok sasaran dari peraturan bupati ini adalah para pengusaha pondok wisata. secara umum pengusaha bersifat heterogen, para pengusaha membangun terlebih dahulu kemudian melakukan perijinan, hal tersebut dilakukan karena mereka merasa 
kurang informasi terkait legalitas usaha pondok wisata. Sehingga lebih menyulitkan pemerintah dalam melaksanakan kebijakan yang tertuang dalam peraturan bupati tersebut.

b. Tingkat Komitmen dan Keterampilan Aparat dan Implementor

Kurang tegasnya aparat dan implementor dalam melaksanakan kebijakan, aparat seharusnya komitmen terhadap tujuan yaitu melakukan pengaturan kembali jasa akomodasi dengan lahan sempit, tidak hanya meningkatkan pendapatan daerah dengan mengabaikan usaha yang melakukan pelanggaran.

2. Faktor Pendukung

a. Keterpaduan Hierarki dalam dan AntarLembaga Pelaksana

Terpadunya pembagian kerja di dalam

Dinas Pariwisata dan terjadinya komunikasi yang baik antara Dinas Pariwisata dengan Dinas Penanaman Modal dan Pelayanan Terpadu Satu Pintu atau Dinas Pariwisata dengan Satuan Polisi Pamong Praja. Munculnya koordinasi yang intensif menjadi salah satu komponen penting dalam meningkatkan peluang keberhasilan implementasi suatu kebijakan.

b. Potensi Meningkatkan Pendapatan Asli Daerah

Dengan ditetapkannya peraturan ini, akan semakin banyak usaha masyarakat menengah kebawah dengan lahan sempit dapat disewakan kepada wisatawan sehingga dapat memunculkan potensi dalam meningkatkan PAD.

\section{KESIMPULAN}

Implementasi Peraturan Bupati No 6 Tahun 2016 secara umum belum berjalan optimal. Masih terjadi pelanggaran yang dilakukan oleh pengusaha, terjadi pembiaran oleh pemerintah terhadap pelanggaran tersebut, dikarenakan pemerintah menginginkan pendapatan dari pajak usaha. Strategi yang dirancang hanyalah strategi pelaksanaan yang dalam konsep desa wisata, namun strategi tersebut tidak selaras dengan kenyataan dilapangan. Adanya keterpaduan hierarki, komunikasi dan kerjasama yang baik antara aktor serta potensi meningkatkan PAD menjadi faktor pendukung implementasi, sedangkan faktor penghambatnya ialah keragaman perilaku kelompok sasaran, tingkat komitmen dan keterampilan aparat

\section{SARAN}

Pemerintah Kabupaten Badung melakukan evaluasi secara cermat mengenai implementasi peraturan bupati tersebut, memberikan sosialisasi kepada pengusaha tentang persyaratan teknis usaha pondok wisata. Serta melakukan tindaklanjut terhadap ketidakselarasan strategi dengan kenyataan di daerah. Dalam melaksanakan suatu kebijakan Pemerintah Kabupaten Badung tetap mempertahankan komunikasi dan kerjasama yang baik antara aparatur terkait serta meningkatkan komitmen dan keterampilan aparatur dalam pelaksanaan kebijakan. Serta dalam meningkatkan pendapatan daerah tidak melupakan tujuan dari kebijakan tersebut.

\section{DAFTAR PUSTAKA}

Agustino, Leo. 2016. Dasar-Dasar Kebijakan Publik. Bandung: Alfabeta.

Creswell, John W. 2012. Research Design: Pendekatan Kualitatif, Kuantitatif, dan Mixed. Yogyakarta: Pustaka Pelajar.

Grindle, Merille S (ed.). 1980. Politics and Policy Implementation in the Third World. New Jersey : Princeton University Press.

Miles, Mattew. Hubberman, A Michale, Saldana. 2014. Qualitative Data Analysis: A Metode Sourcebook. Sage Publication

Pasolog, Harbani. 2008. Kepemimpinan Birokrasi. Bandung: Alfabeta.

Peraturan Bupati Badung Nomor 6 Tahun 2016 Tentang Standarisasi Usaha Pondok Wisata di Kabupaten Badung.

Salusu, J. 1996. Pengambilan Keputusan Stratejik: Untuk Organisasi Publik dan Organisasi Nonprofit. Jakarta: Grasindo 